\title{
The Effects and Adaptive Design Methods of Urban Space toward Flood
}

\author{
Rui Nie ${ }^{1, a *}$, Lijie Wang ${ }^{1, b}$, PingZhang ${ }^{1, c}$ Xiuping Zhao ${ }^{1, d}$ \\ ${ }^{1}$ School of Architectural and Art Design, Hebei University of Technology, the People's Republic of \\ China
}

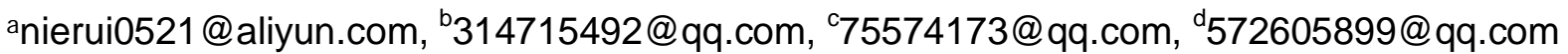

Keywords: Flood, Urban Space, Adaptive design

Abstract. Flood is one of the most important diasaters in city and occurs frequently in recent years.It has highly spatial relevance. The urban spatial relevance of urban flood risk are analyzed in the paper and adaptive methods of urban space toward flood, including avoiding high-risk areas , building buffer space for urban flood and constructing urban adaptive space are summerized , which provide references for urban space design to prevent flood.

\section{Introduction}

In recent years, serious water and soil erosion and frequent rainstorm because of global warming and the acceleration of urbanization process cause urban loss because of flood increaseing by years. Flood has become one of the most important disasters in city, which occurs frequently. Taking china as an example, in the 2000-2010 decade, the direct economic loss because of flood in the four municipalities including Beijing, Tianjin, Shanghai and Chongqing, reached 217 million, 236 million, 1011 billion and 32028 billion yuan respectively.Urban flood control has become an important part of urban disaster mitigation.

In the past, the countermeasures of urban flood mitigation mainly are structural measures, such as building dam, which not only reduce the frequency of floods, but also increase the potential loss of flood because of more population and assets concentrated to the protected area. As one of the important strategies of urban disaster mitigation, the adaptive design of urban space belongs to non-structural strategy, which can reduce the potential intensity of flood effectively and decrease human and economic losses caused by flood in spite of the frequency of flood not altered.

\section{Spatial Relevance of Urban Flood Risk}

The spatial character of a risk is defined by spatial effects that might occur if a hazard turns into a disaster or an appropriate spatial planning response [1]. Urban risk is the combination of hazard potential and vulnerability.

Spatial Relevance of Flood Hazard.Every hazard has a spatial dimension which means disasters take place somewhere. But the occurrence of spatially relevant hazards is limited in a certain disaster area which is regularly or irregularly prone to hazards.Flood belongs to higher spatial relevance which occurs in only certain areas[2].

Spatial Relevance of Urban Flood Vulnerability. Vulnerability as social response focuses on coping responses including societal resistance and resilience to hazards. Urban spatial structure and 
form is the external expressive form of the interaction between society, culture, economy and environment[3].

Effection of Urbanization on Rainstorm. The rainstorm induced by the irrational development of urban space, is controllable certainly. Firstly, the irrational developments of urban space exacerbate urban heat island effect.At the same time, the collision of updraft caused by the rising temperature of urban surface and warm air result in the instability of urban air layer and form torrential rain. Secondly, the increasing urban pollutants which are not discharged timely offer the condensation nuclei of raindrop over the city which enhance the potential rainstorm with the updraft and cloud cover increasing.

Three-dimensional Development of Urban Space. The use of three-dimensional urban space produces extensive underground space with multiple uses, such as public space used by metro, business, entertainment, parking, facilities etc and multi-use space used by equipments in high-rise residential buildings, community activities, and private storage etc. Underground space is more serious to be influenced by flood. For the people in underground space, it is more difficult to escape because the door can not be opened for the water pressure.Therefore, the casualties and property losses in underground space are more likely to be larger than in ground buildings.

Changes of Land Cover Types in River Basin. In the natural conditions, the ground of river basin is covered with plants and water and has good permeability. With the urban develepment, urban surface is mainly coverd with man-made materials which lead to the amount of rainwater infiltration decreasing, surface runoff increasing and regional water retention capacity reducing. With the surface area of wetlands and water reduction, the ability of urban surface to accommodate rain is weakened which leads to the amount of overall rainwater flow increasing.In sum, the changes of land cover types of city, because of destroying the rain hydrological cycle and increasing the pressure on urban drainage, become one of the most important direct causes of urban flood formation.

\section{The Adaptive Design Methods of Urban Space}

Adaptation comes from ecology which is used to define environmental contingencies within a certain range.It is the ability which can ensure person to survive and last through appropriate changes to adapt to the new situation [4].

In urban complex ecosystem, different from passive reactions of natural ecosystems to disaster risk interference,urban ecosystem is a complex composed of person with initiative mainly, which not only means passive acceptance to the limitation of natural environment for human activities, but also means the active reactions of humanity activities to utilizing natural environment through learning ability and technical progress.In spite of not controlled fully,flood is the hazard which is severely influenced by human. Urban space, through adjusted to better morphology and usage patterns, has the ability to adapt to the impacts caused by hazards, and reduce the impact of disasters to the minimum.

Avoiding High-risk Areas of Flood. High-risk areas of flood refer to the urban regions that are the easiest to be inundated in urban space. Avoiding high-risk areas is the most direct method to adapt flood disaster.These regions in urban space can be used as urban open recreational space such as park, lake, square to reduce the urban disaster risk. 
Building Buffer Space for Urban Flood. The buffer space for urban flood refers to the urban spaces which are affected firstly when flood occurs and can limit the further influence on urban space effectively. The target of building buffer space aims at restricting the flood scope in the buffer space and reducing the harm of flood to other urban space.

In the process of urban flood control, firstly, the design methods such as widening the dam and afforesting the dam combined with the construction of urban landscape are used to not only offer the urban recreation space usually but also provide enough space to hold a suddenly increaseing water when flood happens in order to reduce the possibility of overflowing. Secondly, combined with the natural topography of the urban specific conditions, the urban regions with lower terrain are used as detention basin to store the flood that can not be removed immediately temporarily and reduce the flood discharge pressure of downstream rivers.

Adaptive Design of Urban Space. Adaptability of urban space refers to that urban space can convert the use mode quickly to adapt to the impacts of flood when flood happens and protect urban normal operation maximumly.

Adaptive Design of Urban architecture space. The most basic requirement of architecture space is safe. Adaptive architecture space means to minimize the impact of disasters and adapt the requirements of disasters. For example, through the long-term experience summary, Dai Ganlan style dwellings are the traditional architectural form of the local residents to deal with Lancang river flood every year. Because of the height of the ganlan style dwellings enough to dry the floor against floods submerged, none will have any impact on local resident's life although flood happers every year. On the contrary, flood is benefit to local agricultural production because of the dirt of the soil cleaned[5].

Adaptive Design of Urban Transport space.The destructive effects of flood on the city not only reflect on streets and houses flooded and casualties and property losses, but also embody in the difficulty to rescue. When flood happens, the adaptation of urban transport space reflects in the quick change from usual mode of land transport to disaster mode of water transport.

For example, in order to cope with regular flood every year, the local residents in the southwest town of china set higher platforms on both sides of the road and the buildings are all built on the platforms. In annual flood season, the roads are always translated into the space to accommodate and guide flood and become the rivers. Town transportation changes from land transport on the roads to water transport in the river whose location are the roads at ordinary times. At the same time, the land transportation changes from on the road to on the platform locating on both sides of the rivers.

Adaptive Design of Urban Space Utilization Pattern. In order to adapt to the impacts of flood, the utilization of urban space need to be designed as an flexible mode which can be suited to space function converting from usual use to disaster use when needed.For example, in Ankang,one of the ancient towns in china, there is a long dam with extensive peach tree and willow on it was constructed outside the south door of the town and connect with the highland, whose function was not only to protect the town from floods and enrich the town landscape in normal times, but also to help the local residents to evacuate along the dam to the highland when flood could not be controlled and had threatened the resident's life safety[6].

\section{Conclusions}

1. The adaptive design of urban space belongs to non-structural strategy, which can reduce the potential intensity of flood effectively and decrease human and economic losses caused by flood. 2 . 
Urban flood risk has the great relevance with urban space, including two aspects of spatial relevance of flood hazard and urban vulnerability. 3. Adaptive design of urban space plays an important role during the process of urban flood mitigation.4. Three Adaptive design methods of urban, including avoiding high-risk areas of flood, building buffer space for urban flood and adaptive design of urban space, have the ability to adapt to the impacts caused by flood hazard, and reduce the impacts of flood to the minimum.

\section{Acknowledgements}

This work was financially supported by the Hebei Province Social Science Foundation (HB13YS043), Hebei Province Humanities and Social Science Research key Project of Colleges and Universities (SD151097) , Hebei Province Social Science Foundation (HB14SH027) and Hebei Province Culture and Arts Science Research Project (HBWY2014-Z-A007)

\section{References}

[1] Mark Fleischhauer: Resilience of Cities to Terrorist and other Threats (Springer Publications 2008) p.280-281

[2] Mark Fleischhauer: The Role of Spatial Planning in Strengthening Urban Resilience. In: H.J. Pasman and I.A. Kirillov, Resilience of Cities to Terrorist and other Threats. Springer Science + Business Media B.V. 2008 , 281

[3] Cutter. S. L: Progress in Human Geography, Vol. 20(1996), No.4. p.529-539

[4]Chenwei: Adaptability theory research of modern urban space construction (China Building Industry Press, Beijing 2010).

[5]Linggao Zhang: Seven Theories of Artisan knowledge (China Building Industry Press, Beijing 2002).

[6]Qingzhou Wu: Research on Flood Control of Chinese Ancient Cities (China Building Industry Press, Beijing 2009). 